\section{Original Research}

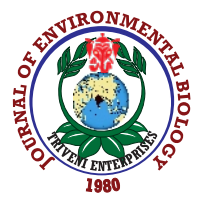

DOI : http://doi.org/10.22438/jeb/41/6/MRN-1420

Journal Home page : www.jeb.co.in $\star$ E-mail : editor@jeb.co.in

\title{
Functional characterization of bacteria isolated from different gut compartments of white grub, Anamola dimidiata, larvae
}

\author{
K.R. Msango Soko ${ }^{1}$, R.C. Bhattacharya ${ }^{2}$, B. Ramakrishnan ${ }^{3}$, K. Sharma ${ }^{1}$ and S. Subramanian ${ }^{1 *}$ \\ 'Division of Entomology, ICAR-Indian Agricultural Research Institute, New Delhi-110012, India \\ ${ }^{2}$ ICAR-National Institute for Plant Biotechnology, New Delhi-110 012, India \\ ${ }^{3}$ Division of Microbiology, ICAR-Indian Agricultural Research Institute, New Delhi-110 012, India \\ *Corresponding Author Email : entosubra@yahoo.co.in
}

Paper received: 07.02 .2020

Revised received: 21.05 .2020

Accepted: 13.07 .2020

\section{Abstract}

Aim: The aim of the present study was to isolate and characterize cellulolytic, lipolytic and nitrate reductase activities in the bacteria isolated from the gut of white grub, Anamola dimidiata larvae.

Methodology: Field collected third instar scarab larvae were dissected under aseptic conditions and inoculated on different bacteriological media to isolate gut bacteria. Identification of these isolates was carried out by amplifying and sequencing the 16S rRNA gene and comparing with their closest relatives in GenBank. Cellulolytic, lipolytic and nitrate reductase activities were assayed using Carbonmethyl cellulose (CMC), Rhodamine $B$ and nitrate broth media.

Results: The majority of culturable bacteria in the gut of $A$. dimidiata belonged to two phyla: Firmicutes $(62.5 \%)$ and Proteobacteria (37.5\%). Forty aerobic and eleven anaerobic bacterial strains were isolated and tested for cellulolytic, lipolytic and nitrate reductase activity, and twenty seven and thirty one cellulolytic and lipolytic gut bacteria were identified, respectively, with 19 isolates exhibiting both activities whereas ten facultative anaerobic bacteria isolates were positive for nitrate reductase activity.

Interpretation: These bacterial isolates may be good
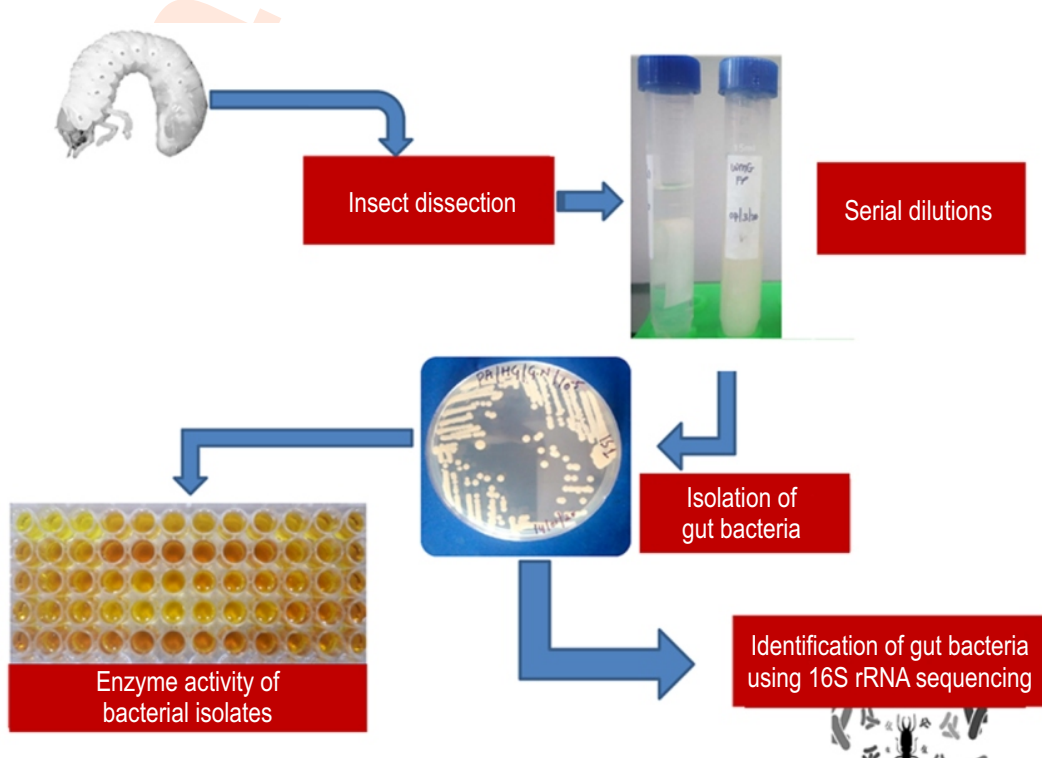
sources for profiling novel isolates and enzymes for industrial use besides identifying new solutions for pest control.

Key words: Aerobic, Anamola dimidiata, Facultative anaerobes, Gutbacteria

How to cite : Msango Soko, K.R., R.C. Bhattacharya, B. Ramakrishnan, K. Sharma and S. Subramanian: Functional characterization of bacteria isolated from different gut compartments of white grub, Anamola dimidiata, larvae. J. Environ. Biol., 41, 1526-1535 (2020). 


\section{Introduction}

The gut of insects is a complex environment that is inhabited by microbes whose localization and functional role vary considerably. Some insects posses special gut modifications such as paunches that influence endogenous microbial community structure (Jones et al., 2019). Recent studies have shown that insects through their microbial associations have developed integrative strategies to contend challenges they encounter in their environments such as modulation of foraging behavior, enhancement of resistance to pathogens, digestion of recalcitrant food sources, vitamin provisioning and metabolism of xenobiotic substances (Akami et al., 2019; Jones et al., 2019). Among these are bacteria which colonize special niches within the gut and develop relationship with either other microbes or their hosts. With the current concerns of climate change related events such as pest outbreaks and global warming due to increased use of fossil fuels; insects with cellulose converting systems alongside with their associated evolutionary lineages with bacteria have been suggested as new targets for insect pest control as well as providing researchers with information on managing plant biomass for sustainable alternative energy sources (Wanatable and Tokuda, 2010; Handique et al., 2017).

The family Scarabaeidae under the order Coleoptera with over 30,000 species are exclusively herbivorous or saprophagous with the ability to decay plant material, including roots and organic matter (Huang and Zhang, 2013; Huang et al., 2012). The scarab beetles are economic pests of most agricultural crops in many parts of the world (cereals, groundnuts, pulses, sugarcane, plantation crops, turf, pastures and solanaceous crops) where the grubs are root feeders and their beetles feed on the leaves of host plants (Jackson and Klein 2006; Theurkar et al., 2012; Bhattacharyya et al., 2017). Scarabs are one of the major edaphic invertebrates with an estimated biomass of 5-54 larvae $\mathrm{m}^{-2}$ reaching up to 600 larvae $\mathrm{m}^{-2}$ in severe outbreaks (Majeed et al., 2014). The feeding ability of different scarab beetle grub species appear to differ significantly and this in part is believed to be due to their symbiotic gut bacteria which may be shaping their plasticity (Huang and Zhang, 2013; Zhang et al., 2018). The guts of these saprophagous macro invertebrates also play a critical role in transforming soil organic matter and in carbon and nitrogen cycle of terrestrial environments.

This in part is due to a complex microbial community in their intestinal tract which depolymerizes cellulosic or lignocellulosic components in their diet into simpler digestive products that can be assimilated by the host (Egert et al., 2003; Lemke et al., 2003). Many strategies are currently utilizing microbes based enzymes to degrade plant biomass for bioenergy production and scarab larvae have been suggested as a good model as they consume celluloses from multiple sources and have the ability to extract nutrients and energy from these sources with the help of endogenous enzymes complimented with proteinases and cellulolytic enzymes produced by symbiotic microbes. Cellulose digestion efficiency estimated up to $65 \%$ of scarab diet is attributed to the bacteria within the scarab larval intestinal tract which produce a combined action of enzymes such as endoglucanases, exoglucanase and $\beta$-glucosidase (Handique et al., 2017). Due to a wide diversity of microbes in the gut of scarab larvae which are involved in lignocellulosic degradation through enzymatic and fermentative processes, scarabs stand to assist the biofuel industries to prospect for new sources of efficient enzymes of microbial origin (Huang et al., 2010). Many strategies are currently utilizing microbes based enzymes to degrade plant biomass for bioenergy production and scarab larvae have been suggested as a good model as they consume celluloses from multiple sources and have the ability to extract nutrients and energy from these sources with the help of endogenous enzymes complimented with proteinases and cellulolytic enzymes produced by symbiotic microbes. The aim of the present study was to isolate and characterize cellulolytic, lipolytic and nitrate reductase activities in the bacteria obtained from the gut of white grub, Anamola dimidiata larvae.

\section{Materials and Methods}

Insect collection: The third instar $A$. dimidiata grubs were collected from a potato field at Modipuram, UP, India. The insects were transferred to our laboratory in aerated plastic jars (with potato slices) and maintained under a regime of 16:8 hr light and dark period with rearing temperature of $26 \pm 1^{\circ} \mathrm{C}$ and $70 \% \mathrm{RH}$ at the Division of Entomology, IARI, Pusa Campus; New Delhi, India until they were dissected. The larvae were starved for $24 \mathrm{hr}$ to clear the gut prior to dissection.

Insect dissection and isolation of aerobic gut bacteria: The larvae were rinsed in double distilled water for $30 \mathrm{sec}$ followed by $70 \%$ ) ethanol for $60 \mathrm{sec}$ and again rinsed in double distilled water for $30 \mathrm{sec}$ to remove the disinfectant. The sterilized larvae were dissected using sterile microscissors under laminar flow to extract the gut. The extracted gut was separated into midgut (MG), anterior-hindgut (AHG), fermentation chamber (FC) and posthindgut $(\mathrm{PHG}$ ) and each compartment was briefly rinsed in sterilized $0.85 \% \mathrm{NaCl}$ and placed in a sterile $1.5 \mathrm{ml}$ eppendorf tube containing sterilized $0.85 \% \mathrm{NaCl}$ and homogenized with a sterile homogenizer. The gut homogenates from various compartments were serially diluted and inoculated on autoclaved Nutrient Agar, Tryptone Soy Agar and Pseudomonas Isolation Agar (HiMedia Pvt. Ltd. Mumbai, India). The inoculated plates were incubated at $37^{\circ} \mathrm{C}$ for $24-48 \mathrm{hr}$. The bacterial colonies were differentiated based on their color, size, and morphology and a single representative isolate of each morphotype was purified by streaking on corresponding agar plates repeatedly until the purity of each culture was obtained. Enumeration of the isolates was performed by calculating the number of CFUs and the values of mean colony counts were used for calculating viable counts of cultivable bacteria and expressed as CFU in $1 \mathrm{ml}$ of sample.

Isolation of anaerobic gut bacteria: To profile anaerobic gut bacteria from $A$. dimidiata, only the midgut and fermentation chamber of $A$. dimidiata larvae were used. Fully grown $3^{\text {rd }}$ instar 
larvae were pre-chilled for 1-2 min to immobilize them and also for easy handling. The larvae were then surface sterilized in $70 \%$ ethanol for $60 \mathrm{sec}$ followed by rinsing in double distilled water before dissection. Individual insects were dissected in aseptic conditions under lamina flow using aseptic dissection scissors and forceps and the midgut and fermentation chamber were removed and immediately transferred to a $1.5 \mathrm{ml}$ sterile eppendorf tube containing sterile $0.85 \% \mathrm{NaCl}$ solution and sealed with parafirm to avoid exposure to oxygen. Three separate samples of each gut compartment were prepared as described above and the samples were kept in $-20^{\circ} \mathrm{C}$ awaiting further downstream processes. Samples were homogenized in an anaerobic environment comprising an air tight chamber sterilized with alcohol and continuously flashed with $\mathrm{CO}_{2}$. Serial dilutions were inoculated on Thioglycollate media (composed of Tryptone, $20 \mathrm{~g} \mathrm{l}^{-1}, \mathrm{NaCl} 2.5 \mathrm{~g} \mathrm{l}^{-1}, \mathrm{D}(+)$-Glucose $5.5 \mathrm{~g} \mathrm{l}^{-1}$, L-Cystine $0.5 \mathrm{~g}^{-1}$, Dipotassium Phosphate, Sodium Sulphite $0.2 \mathrm{~g} \mathrm{l}^{-1}, 1.5 \mathrm{~g} \mathrm{l}^{-1}$, Methylene blue $0.002 \mathrm{~g} \mathrm{l}^{-1}$, Sodium Thioglycollate $0.6 \mathrm{~g} \mathrm{l}^{-1}$ and Agar $15 \mathrm{~g} \mathrm{l}^{-1}$ ) and incubated under anaerobic condition at $28^{\circ} \mathrm{C}$. The media was autoclaved at $121^{\circ} \mathrm{C}$ for $20 \mathrm{~min}$. The number of colonies was recorded after $72 \mathrm{hr}$ and used to calculate the initial inoculum size. The colonies were purified by streaking multiple times on corresponding media under anaerobic conditions until pure cultures were obtained.

DNA extraction and PCR amplification: Distinct representative purified colonies of bacteria were selected for identification based on 16S rRNA gene sequence analyses. Individual, purified bacterial isolates were grown on nutrient broth for $24 \mathrm{hr}$ at $37^{\circ} \mathrm{C}$. After $24 \mathrm{hr}$ of growth, the broth cultures were centrifuged at $13,000 \mathrm{rpm}$ to separate the pellet and supernatant. The supernatant was discarded and the pellet was used for DNA extraction using a modified cetyltrimethylammonium bromide (CTAB) method. The extracted DNA quality was checked on an agarose gel and quantified using a NanoDrop: 3300 FluoroSpectrometer (Thermo Scientific, Wilmington, DE, USA). The 16S rRNA of each isolate was amplified by PCR using BioLine Master Mix and eubacterial primers 27F- $(10 \mu \mathrm{M}), \quad\left(5^{\prime} \rightarrow\right.$ AGAGTTTGATCCTGGCTCAG $\left.\rightarrow 3^{\prime}\right)$ and 1492R- $(10 \mu \mathrm{M}),\left(5^{\prime} \rightarrow\right.$ AAGGAGGTGATCCAGCCGCA $\rightarrow 3$ ') (Takara Bio India Pvt. Ltd). Each reaction contained approximately $50 \mathrm{ng}$ DNA, $25 \mu$ l Master Mix (2X) and $0.5 \mathrm{mM}$ of each primer. The PCR was carried out in a Bio-Rad C1000-thermal cycler (Bio-Rad Laboratories Inc, Berkeley, CA, USA) as follows: one cycle at $94^{\circ} \mathrm{C}$ for $5 \mathrm{~min}, 35$ cycles at $94^{\circ} \mathrm{C}$ for $1 \mathrm{~min}, 52^{\circ} \mathrm{C}$ for $1 \mathrm{~min}$ and $72^{\circ} \mathrm{C}$ for $1 \mathrm{~min} 40 \mathrm{sec}$, followed by $72^{\circ} \mathrm{C}$ for $10 \mathrm{~min}$ and $4^{\circ} \mathrm{C}$ forever. PCR products were examined by electrophoresis in $1.2 \%$ agarose gel, and bands were visualized by staining with ethidium bromide.

The gels were run at $100 \mathrm{~V}$ for $1 \mathrm{~h}$ in TAE buffer $(40 \mathrm{mM}$ Tris-acetate, $1 \mathrm{mM}$ ethylene-diamine-tetra-acetic acid (EDTA); $\mathrm{pH}$ 7.4). Gels were visualized under UV in the Gel Documentation system of Alpha ImagerTM gel imaging system (Alpha Innotech, San Leandro, CA, USA). Sequencing of 16S rRNA gene was outsourced from a private lab (AgriGenome Labs Pvt. Ltd, Kerala,
India). Only high-quality sequences were checked with their closed relatives using the NCBI-BLAST algorithm and bacterial isolates were identified based on their similarity with existing sequences. The nucleotide sequences obtained were submitted to the GenBank database and assigned with accession numbers.

Qualitative screening for cellulolytic and lipolytic gut bacteria: Cellulolytic gut bacteria were screened by inoculating the isolates on Carboxyl Methyl Cellulose (CMC) agar plates following a protocol as described by Handique et al. (2017). Screening for the presence of lipolytic bacteria was carried out by qualitative plate assay using Rhodamine B media following a protocol as given by Feng et al. (2011). The cellulolytic and lipolytic index of the isolates was scored as follows: Enzyme activity (index) $=$ Diameter of clear zone + colony- Diameter of colony $(\mathrm{mm}) /$ Diameter of colony $(\mathrm{mm})$.

Cellulolytic activity assay: Cellulolytic activity was estimated by measuring the amount of reducing sugars released following the DNSA method of Miller (1959). Individual bacterial isolates with high CM Case activity were inoculated in cellulase production media containing $10 \mathrm{~g} \mathrm{CMC}, 0.2 \mathrm{~g}$ magnesium sulphate, $0.75 \mathrm{~g}$ potassium nitrate, $0.5 \mathrm{~g}$ Dipottasium phosphate, $0.2 \mathrm{~g}$ iron sulphate, $0.04 \mathrm{~g}$ calcium chloride, $2 \mathrm{~g}$ yeast extract and $1 \mathrm{~g} \mathrm{D}$ glucose [pH 7.0] (Lisdiyanti et al., 2012). The bacterial cultures were incubated for $37^{\circ} \mathrm{C}$ for $36 \mathrm{hr}$. After incubation, the cell-free crude enzyme produced was collected by centrifugating the samples at $10000 \mathrm{rpm}$ for $15 \mathrm{~min}$ at $4^{\circ} \mathrm{C}$. The cell-free extract was kept at $4^{\circ} \mathrm{C}$ until next use as enzyme source.

Lipolytic assay: Lipase activity of bacterial isolates was estimated by using $p$-nitrophenyl butyrate (PNPB, $27 \mathrm{mM}$ ) as per the method described by Zibaeea et al. (2012) with slight modification as follows: each reaction mixture consisted of $50 \mathrm{\mu l}$ of PNPB solution dissolved in $50 \mathrm{mM}$ Tris- $\mathrm{HCl}$ buffer, $\mathrm{pH}$ 8.0. The reaction mixture was mixed with $15 \mu$ l of enzyme source and incubated at $37^{\circ} \mathrm{C}$. After 30 min incubation period, $50 \mu$ l of distilled water was added to each tube (control and treatment) and the $\mathrm{OD}$ of the mixture was read at $410 \mathrm{~nm}$ in micro-plate reader (Eon Microplate Reader, BioTek Instruments India, Ltd) using the Gen5 ver. 2.4 software. Lipolytic activity was calculated by measuring the release of para-nitropheyly (pNP) using standard solutions of $\operatorname{pNP}\left(0.01\right.$ to $\left.0.1 \mu \mathrm{g} \mathrm{ml}^{-1}\right)$. One unit of enzyme releases $1.0 \mu \mathrm{mol}$ of p-nitropheyly per minute.

Nitrate reductase assay: As the reduction of nitrate is generally an anaerobic respiration in which an organism derives its oxygen from nitrate, we attempted to assay the anaerobically isolated gut bacterial isolates to establish if they may also be involved in nitrate reduction following a protocol for qualitative nitrate reductase assay as described at Sigma-aldrich.com. In brief, the anaerobic bacterial isolates were inoculated in nitrate broth (peptone $5 \mathrm{gl}^{-1}$, meat extract $3 \mathrm{gl}^{-1}$, potassium nitrate $1 \mathrm{gl}^{-1}$ - final $\mathrm{pH}$ 7.0. The samples were incubated at $37^{\circ} \mathrm{C}$ for $24 \mathrm{hr}$. After incubation, five drops of sulfanilic acid and a-Naphthylamine solution (in $5 \mathrm{~N}$ acetic acid) were added to the tubes containing 
cultures and shaked thoroughly. A distinct appearance of red or pink color after few minutes indicated nitrate reduction. Zinc powder was added if the tubes did not turn pink after addition of the reagents mentioned above. A colorless medium after addition of zinc indicated nitrate reduction, while pink color was scored as negative.

Phylogenetic analysis: To assess the phylogenetic relationships between the bacterial isolates from $A$. dimidiata, 16S rRNA gene sequences were assembled and aligned using BioEdit Sequence Alignment Editor V. 7.0.5.3 (Hall 1999) and was analyzed using MEGA 7.0 (Tamura et al., 2004). Phylogenetic trees were constructed by the neighbor-joining method with Kimura two-parameter correction (Kimura, 1980). To calculate the support for each clade, bootstrap analysis was performed with 1000 replications (Felsenstein, 1985).

Data analysis and statistics: Analyzable data (cellulolytic indices, lipolytic indices, among others) were subject to descriptive statistics, t-test and analysis of variance (ANOVA) using the SAS software. Tukey's honest significant difference (HSD) was used to evaluate differences between each factor at $P=0.05$.

\section{Results and Discussion}

The results of gut bacteria enumeration suggested that colonization of gut bacteria across the gut compartments appeared to be even as the results on colony forming units (CFUs) indicated no significant differences between the gut compartments on culturable aerobic $(M G=8.01 \pm 1.19$ $\mathrm{AHG}=8.82 \pm 0.58 \mathrm{FC}=8.75 \pm 0.60, \mathrm{PHG}=8.66 \pm 0.62, \mathrm{P}=0.8825$ ) and anaerobic gut bacterial isolates (midgut=10.64 \pm 1.30 Fermentation chamber $=10.79 \pm 1.17$, $t$-value $(4 d f)=0.09, P$ $>\mathrm{t}=0.9356)$ from $A$. dimidiata. Generic identification of isolates was carried out by $16 \mathrm{~S}$ rRNA gene sequencing analyses. Similarity checks of the resulting 40 sequences for aerobic and 11 sequences for anaerobic bacterial isolates were carried out with closest relatives in NCBI and almost all isolates had similarity $\geq$ $97 \%$ with their closest relatives from NCBI database.

A single aerobic isolate, WG37-MG and one anaerobic isolate (WG-ANE-MG5) belonging to Proteobacteria had only similarity to the extent of $96 \%$ and $93 \%$, respectively, with their closest relatives from GenBank, thus indicating that these two isolates may be unique ones. The majority of culturable bacterial isolates from $A$. dimidiata belonged to Firmicutes and Proteobacteria. The results further indicated that $A$. dimidiata is mainly dominated by Firmicutes $(62.5 \%$ ) and Proteobacteria $(37.5 \%)$. These results also suggest that the majority of culturable anaerobic gut bacteria belong to the families Firmicutes (55\%) and Proteobacteria (45\%). A study by Zhang and Jackson (2008) reported that a core community of gut bacteria is present in the fermentation chamber of Costelytra zealandica, with the majority of bacteria being located in the hindgut wall. A number of aerobic and anaerobic cellulolytic bacteria belonging to the family Enterobacteriaceae with endo-xylanase and beta-xylosidase have been lately isolated from the hindgut of Holotrichia parallela, another species of scarab beetles prevalent in China (Zhang et al., 2018). The sequences were submitted to GenBank and assigned accession numbers as outlined in Tables 1 and 2.

Insects employ diverse mechanisms that enable them to survive in diverse ecological niches. Center to these are enzymatic proteins which can be produced by the insects complemented by microbial associations that are used as digestive helpers which gives the insects the plasticity to survive on diverse nutrient sources (Mika et al., 2013). The identified gut bacterial isolates were screened for cellulolytic activity by using CMC agar plate assay. Highly significant differences $(P<.0001)$ were found between the bacterial isolates on their ability to hydrolyze CMC (Table 3). The cellulolytic bacterial isolates are dominated by three major genera namely Bacillus (67\%), Pseudomonas (22\%) and Enterobacter(11\%).

The genera Bacillus and Pseudomonas have been reported to contain species with an ability to produce cellulolytic enzymes (Kothari et al., 2013; Kumar et al., 2014) and it is apparent from the results of the present study. The previous reports on gut bacterial isolates from Coleopteran insects suggest that Bacillaceae dominate the cellulolytic gut bacterial symbionts in insects. A comparative analysis of four gut compartments indicate that the fermentation chamber and anterior hindgut regions harbour cellulolytic gut bacteria predominantly. Henrissat and Bairoch (1993) indicated that the enzymatic digestion of cellulose is a complex process requiring a diverse group of glycoside hydrolases called cellulases. Endoglucanases (EC3.2.1.4) attack the cellulose molecule randomly and dissociate after making few cleaves. Exoglucanases (EC-3.2.1.91) remove subunits at both reducing and non-reducing ends of cellulose, releasing either cellobiose or glucose and $\beta$-glucosidase (EC3.2.1.21) completely hydrolyze cellobiose to glucose. A number of insects such as Hieroglyphus banian, D. caroloina grasshopper, Periplenata americana, Odontotermes obesus and Philosomia ricini have been reported to possess endogenous cellulases, particularly, Beta-glucosidases (Taggar, 2015). The results of present study on cellulolytic assay reveal that the gut bacterial isolates from Anamola dimidiata possess endoglucanase, exoglucanase and beta-glucosidase activities. The cellulolytic bacterial isolates are significantly enriched in the hindgut, especially in the fermentation chamber, and this may be an evolutionarily acquired anatomical modification to harbour certain specific symbionts aiding in digestion of cellulose in scarabaeids. Several aerobic hemi-cellulolytic and endo-xylanase bacterial strains had earlier been isolated from the fermentation chamber of scarabaeid, Holotrichia parallela (Zhang et al., 2018).

A single bacterial isolate Bacillus sp. WG42-FC isolated from the fermentation chamber appears to be unique as it possesses significant exoglucanase compared to the rest of the isolates and we presume that this isolate may be associated with exoglucanase production in aiding digestion of cellulose in $A$. dimidiata (Fig. 1). Lipases of microbial origin, particularly bacteria 
Table 1: Culturable aerobic gut bacteria isolated from the gut of $A$. dimidiata

\begin{tabular}{|c|c|c|c|}
\hline Strain ID & GenBank Accession No & Closest relative in GenBank & Similarity $(\%)$ \\
\hline WG36 & MN793065 & Pseudomonas aeruginosa strain 16S-DB2 & 99 \\
\hline WG37 & MN793066 & Pseudomonas aeruginosa strain F18 & 96 \\
\hline WG38 & MN793067 & Pseudomonas aeruginosa strain FMDP002 & 100 \\
\hline WG16 & MN794228 & Bacillus toyonensis strain PK1-17B & 99 \\
\hline WG17 & MN744366 & Bacillus subtilis strain JN005 & 99 \\
\hline WG18 & MN794025 & Bacillus cereus strain S5 & 97 \\
\hline WG02 & MN794224 & Bacillus altitudinis strain B7 & 99 \\
\hline WG03 & MN744374 & Bacillus anthracis strain B12-B41 & 99 \\
\hline WG04 & MN794023 & Enterobacter sp. strain AA150 & 99 \\
\hline WG05 & MN744363 & Enterobacter hormaechei strain IA3 & 100 \\
\hline WG24 & MN795601 & Bacillus cereus strain Cps1 & 100 \\
\hline WG25 & MN795598 & Bacillus subtilis strain EN4 & 98 \\
\hline WG27 & MN794021 & Bacillus cereus strain CPO 4.232 & 100 \\
\hline WG28 & MN744373 & Bacillus cereus strain SBMAX30 & 98 \\
\hline WG29 & MN793061 & Pseudomonas aeruginosa strain NBRITSS & 99 \\
\hline WG30 & MN793062 & Pseudomonas aeruginosa strain 16S-DB6 & 100 \\
\hline WG31 & MN793060 & Bacillus wiedmannii strain IKb-SK-CIFE & 99 \\
\hline WG32 & MN793063 & Bacillus cereus strain FJAT-46988 & 100 \\
\hline WG33 & MN794022 & Pseudomonas aeruginosa strain G RN2-1 & 99 \\
\hline WG39 & MN795599 & Bacillus subtilis strain VM 06 & 100 \\
\hline WG40 & MN795600 & Pseudomonas psychrophila strain KTA & 99 \\
\hline WG41 & MN793068 & Bacillus wiedmannii strain WS4-21 & 98 \\
\hline WG42 & MN795595 & Bacillus cereus strain B24 & 100 \\
\hline WG43 & MN793069 & Pseudomonas aeruginosa strain D1-3 & 100 \\
\hline WG01 & MN794223 & Bacillus cereus strain DCRUST BT FtM- 5 & 99 \\
\hline WG10 & MN794229 & Bacillus velezensis strain B1-6 & 100 \\
\hline WG11 & MN794226 & Bacillus halotolerans strain VSH 03 & 99 \\
\hline WG07 & MN794025 & Pseudomonas sp. strain TRB175 & 99 \\
\hline WG08 & MN793158 & Bacillus cereus strain AK6 & 99 \\
\hline WG09 & MN744375 & Bacillus tequilensis & 100 \\
\hline WG12 & MN744364 & Enterobacter hormaechei & 99 \\
\hline WG13 & MN794227 & Bacillus subtilis subsp. spizizenii & 99 \\
\hline WG14 & MN794230 & Bacillus subtilis strain SES61 & 99 \\
\hline WG15 & MN744365 & Pseudomonas fragi strain 15-D5 & 99 \\
\hline WG20 & MN795596 & Bacillus subtilis strain BJ-DEBCR-31 & 100 \\
\hline WG21 & MN744371 & Bacillus wiedmannii strain FJAT-46982 & 99 \\
\hline WG22 & MN744372 & Pseudomonas sihuiensis strain QSRB1 & 100 \\
\hline WG06 & MN794225 & Bacillus sp. X28 & 98 \\
\hline WG34 & MN794024 & Bacillus mobilis strain PK4-2 & 100 \\
\hline WG35 & MN793064 & Bacillus cereus strain SCS58 & 100 \\
\hline
\end{tabular}

Annotation= MG=Midgut; $\mathrm{AHG}=$ Anterior Hindgut; FC=Fermentation Chamber; $\mathrm{PHG}=$ Posterior Hindgut

Table 2: Anaerobic gut bacteria isolated from the midgut and fermentation chamber of $A$. dimidiata

\begin{tabular}{llll}
\hline Isolate ID & NCBI Accession Number & Closest relative from GenBank & Similarity (\%) \\
\hline WG-ANE-MG2 & MN793166 & Enterobacter sp. strain MFM & 100 \\
WG-ANE-MG3 & MN793167 & Raoultella terrigena strain PGP374 & 99 \\
WG-ANE-MG4 & MN793169 & Bacillus toyonensis strain HBUAS56013 & 99 \\
WG-ANE-MG5 & MN793170 & Escherichia coli strain 244 & 93 \\
WG-ANE-FC1 & MN793159 & Enterobacter sp. strain YB48 & 99 \\
WG-ANE-FC4 & MN793160 & Bacillus subtilis strain 3-17 & 100 \\
WG-ANE-FC6 & MN793161 & Bacillus tequilensis strain JAAKPT & 99 \\
WG-ANE-FC7 & MN793162 & Bacillus subtilis & 99 \\
WG-ANE-FC8 & MN793163 & Bacillus amyloliquefaciens strain FJAT-46318 & 100 \\
WG-ANE-FC9 & MN793164 & Bacillus subtilis strain CL2 & 100 \\
WG-ANE-FC12 & MN793165 & Enterobacter sp. strain MFM & 99 \\
\hline
\end{tabular}


Table 3: Cellulolytic gut bacterial isolates from A. dimidiata

\begin{tabular}{|c|c|c|}
\hline Strain ID & Source & Cellulolytic Index \\
\hline WG16 & $M G$ & $1.13 \pm 0.00$ \\
\hline WG17 & MG & $2.38 \pm 0.15$ \\
\hline WG18 & MG & $0.00 \pm 0.00$ \\
\hline WG36 & MG & $0.00 \pm 0.00$ \\
\hline WG37 & MG & $1.99 \pm 0.38$ \\
\hline WG38 & MG & $1.50 \pm 0.07$ \\
\hline WG02 & $A H G$ & $1.92 \pm 0.08$ \\
\hline WG03 & $A H G$ & $1.09 \pm 0.05$ \\
\hline WG04 & AHG & $1.59 \pm 0.11$ \\
\hline WG05 & AHG & $2.08 \pm 0.37$ \\
\hline WG24 & $A H G$ & $0.87 \pm 0.45$ \\
\hline WG25 & AHG & $1.09 \pm 0.05$ \\
\hline WG27 & $A H G$ & $0.00 \pm 0.00$ \\
\hline WG28 & $A H G$ & $1.61 \pm 0.12$ \\
\hline WG29 & AHG & $0.00 \pm 0.00$ \\
\hline WG30 & AHG & $0.00 \pm 0.00$ \\
\hline WG31 & $A H G$ & $1.70 \pm 0.11$ \\
\hline WG32 & AHG & $0.00 \pm 0.00$ \\
\hline WG33 & AHG & $1.50 \pm 0.00$ \\
\hline WG07 & $\mathrm{FC}$ & $1.82 \pm 0.26$ \\
\hline WG08 & $\mathrm{FC}$ & $0.00 \pm 0.00$ \\
\hline WG09 & $\mathrm{FC}$ & $1.48 \pm 0.04$ \\
\hline WG01 & $\mathrm{FC}$ & $2.04 \pm 0.04$ \\
\hline WG10 & $\mathrm{FC}$ & $0.00 \pm 0.00$ \\
\hline WG11 & $\mathrm{FC}$ & $1.98 \pm 0.24$ \\
\hline WG12 & $\mathrm{FC}$ & $2.43 \pm 0.12$ \\
\hline WG13 & $\mathrm{FC}$ & $1.76 \pm 0.07$ \\
\hline WG14 & $\mathrm{FC}$ & $1.34 \pm 0.09$ \\
\hline WG15 & $\mathrm{FC}$ & $1.73 \pm 0.42$ \\
\hline WG39 & $\mathrm{FC}$ & $0.00 \pm 0.00$ \\
\hline WG40 & $\mathrm{FC}$ & $0.00 \pm 0.00$ \\
\hline WG41 & FC & $0.91 \pm 0.40$ \\
\hline WG42 & $\mathrm{FC}$ & $1.75 \pm 0.07$ \\
\hline WG43 & FC & $0.00 \pm 0.00$ \\
\hline WG06 & PHG & $2.02 \pm 0.20$ \\
\hline WG20 & PHG & $3.52 \pm 0.14$ \\
\hline WG21 & PHG & $0.00 \pm 0.00$ \\
\hline WG22 & PHG & $2.03 \pm 0.16$ \\
\hline WG34 & PHG & $0.00 \pm 0.00$ \\
\hline WG35 & PHG & $2.79 \pm 0.15$ \\
\hline Mean & & 1.16 \\
\hline$p$-Value & & $<.0001$ \\
\hline $\mathrm{SE}(\mathrm{d})$ & & 0.227 \\
\hline Tukey HSD at $5 \%$ & & 0.9237 \\
\hline
\end{tabular}

Annotation: $\mathrm{MG}=$ Midgut; $\mathrm{AHG}=$ Anterior Hindgut; $\mathrm{FC}=$ Fermentation Chamber; $\mathrm{PHG}=$ Posterior Hindgut. Means are cellulolytic index \pm S.E. of bacterial isolates

are used widely in biotechnological applications (Gupta et al., 2003). In addition to cellulases, lipolytic enzymes (EC 3.1.1.3) are vital in insect lipid acquisition, storage and mobilization and are fundamental to many developmental processes (Santana et al., 2017). Thirty-one gut bacterial isolates were found to have lipolytic activity (Table 4). The genus Bacillus dominated the group of lipolytic bacterial isolates with $71 \%$ followed by Pseudomonas
Table 4: Lipolytic index of gut bacteria isolated from A. dimidiata

\begin{tabular}{|c|c|c|}
\hline Strain ID & Source & Lipolytic Index \\
\hline WG16 & MG & $3.13 \pm 0.07$ \\
\hline WG17 & MG & $1.31 \pm 0.10$ \\
\hline WG18 & MG & $1.54 \pm 0.04$ \\
\hline WG36 & MG & $0.00 \pm 0.00$ \\
\hline WG37 & MG & $1.92 \pm 0.04$ \\
\hline WG38 & MG & $2.58 \pm 0.15$ \\
\hline WG02 & $A H G$ & $1.88 \pm 0.07$ \\
\hline WG03 & $A H G$ & $0.00 \pm 0.00$ \\
\hline WG04 & $A H G$ & $0.00 \pm 0.00$ \\
\hline WG05 & $A H G$ & $0.00 \pm 0.00$ \\
\hline WG24 & $A H G$ & $3.13 \pm 0.07$ \\
\hline WG25 & $A H G$ & $2.38 \pm 0.19$ \\
\hline WG27 & $A H G$ & $2.46 \pm 0.04$ \\
\hline WG28 & $A H G$ & $2.54 \pm 0.22$ \\
\hline WG29 & $A H G$ & $1.54 \pm 0.04$ \\
\hline WG30 & $A H G$ & $3.84 \pm 0.15$ \\
\hline WG31 & $A H G$ & $3.50 \pm 0.07$ \\
\hline WG32 & $A H G$ & $1.08 \pm 0.50$ \\
\hline WG33 & $A H G$ & $3.00 \pm 0.13$ \\
\hline WG01 & $\mathrm{FC}$ & $0.00 \pm 0.00$ \\
\hline WG07 & $\mathrm{FC}$ & $1.92 \pm 0.11$ \\
\hline WG08 & $\mathrm{FC}$ & $2.04 \pm 0.34$ \\
\hline WG09 & $\mathrm{FC}$ & $1.79 \pm 0.15$ \\
\hline WG10 & $\mathrm{FC}$ & $1.37 \pm 0.07$ \\
\hline WG11 & $\mathrm{FC}$ & $1.42 \pm 0.04$ \\
\hline WG12 & $\mathrm{FC}$ & $0.00 \pm 0.00$ \\
\hline WG13 & $\mathrm{FC}$ & $1.75 \pm 0.13$ \\
\hline WG14 & $\mathrm{FC}$ & $0.00 \pm 0.00$ \\
\hline WG15 & $\mathrm{FC}$ & $0.00 \pm 0.00$ \\
\hline WG39 & $\mathrm{FC}$ & $1.71 \pm 0.15$ \\
\hline WG40 & $\mathrm{FC}$ & $2.54 \pm 0.18$ \\
\hline WG41 & $\mathrm{FC}$ & $2.88 \pm 0.31$ \\
\hline WG42 & $\mathrm{FC}$ & $2.50 \pm 0.29$ \\
\hline WG43 & $\mathrm{FC}$ & $2.17 \pm 0.51$ \\
\hline WG06 & PHG & $0.00 \pm 0.00$ \\
\hline WG20 & PHG & $1.58 \pm 0.15$ \\
\hline WG21 & PHG & $3.25 \pm 0.07$ \\
\hline WG22 & PHG & $1.54 \pm 0.23$ \\
\hline WG34 & PHG & $1.89 \pm 0.13$ \\
\hline WG35 & PHG & $2.54 \pm 0.11$ \\
\hline Mean & & 1.72 \\
\hline $\mathrm{p}$-Value & & $<.0001$ \\
\hline CV (\%) & & 22.71 \\
\hline $\mathrm{SE}(\mathrm{d})$ & & 0.324 \\
\hline Tukey HSD at $5 \%$ & & 1.316 \\
\hline
\end{tabular}

Annotation: $\mathrm{MG}=$ Midgut; $\mathrm{AHG}=$ Anterior Hindgut; $\mathrm{FC}=$ Fermentation Chamber; $\mathrm{PHG}=$ Posterior Hindgut. Means are lipolytic index \pm S.E. of bacterial isolates

with $29 \%$. In this study, the degradation of $p$-nitrophenyl butyrate to release $p$-nitrophenol by lipase catalyzed hydrolysis was used to quantify lipase activity in selected bacterial isolates. The results of lipase activity of gut bacterial isolates from $A$. dimidiata are presented in Table 5. The measurement of lipase activity among the gut bacterial isolates indicated highly significant differences $(<.0001)$ between the gut bacterial isolates on their lipolytic ability 
Table 5: Lipolytic activity $\left(\mu \mathrm{mol} \mathrm{min}^{-1}\right)$ of selected culturable gut bacteria of A. dimidiata

\begin{tabular}{ll}
\hline Isolate ID & Lipase activity $\left(\boldsymbol{\mu m o l} \mathrm{min}^{-1}\right)$ \\
\hline Control & $0.00 \pm 0.00$ \\
WG-08 & $1.01 \pm 0.09$ \\
WG-16 & $2.35 \pm 0.04$ \\
WG-24 & $2.37 \pm 0.04$ \\
WG-25 & $1.93 \pm 0.07$ \\
WG-27 & $1.10 \pm 0.11$ \\
WG-28 & $2.36 \pm 0.02$ \\
WG-30 & $0.88 \pm 0.01$ \\
WG-31 & $0.99 \pm 0.07$ \\
WG-32 & $2.34 \pm 0.03$ \\
WG-35 & $2.32 \pm 0.00$ \\
WG-38 & $1.40 \pm 0.07$ \\
WG-40 & $2.34 \pm 0.03$ \\
WG-41 & $2.38 \pm 0.02$ \\
WG-42 & $2.34 \pm 0.01$ \\
WG-43 & $0.92 \pm 0.01$ \\
General mean & 1.69 \\
p-Value & $<.0001$ \\
SE(d) & 0.069 \\
Tukey HSD at 5\% & 0.2775 \\
\hline
\end{tabular}

Values are mean \pm S.E.

with bacterial isolate Bacillus sp. WG 41-FC having the highest lipase activity and isolate Bacillus sp. WG08-FC having the lowest activity all isolated from the fermentation chamber. The majority of the screened bacterial isolates were found to have significantly high lipolytic activity suggesting that $A$. dimidiata may be depending more on these lipolytic bacteria to complement its lipid digestion and assimilation. Generally, all the four gut compartments had bacterial isolates with significantly higher lipase activity and their lipolytic activity was not statistically different from each other. Gut bacteria belonging to genera Bacillus, Enterococcus, Enterobacter, Klebsiella and Pseudomonas have been reported from other insects associated with lipolytic activities and also host defense against pathogens (Liu et al., 2018). Rajeshkumar et al. (2013) reported lipolytic activities of Bacillus tequilensis, Bacillus subtilis, Pseudomonas sp. and Bacillus flexus isolated from soil samples.

Eleven anaerobic bacteria cultures isolated from the midgut and fermentation chamber of $A$. dimidiata were subjected to qualitative nitrate reductase assay to screen their ability to break down nitrate. The results indicated that all the anaerobic bacterial isolates possessed the ability to break down nitrate, except for isolate WG-ANE-FC6. Nitrate reductase is an important enzyme that catalyzes the conversion of nitrate to nitrite-ammonia in the $\mathrm{N}$-cycle. The nitrate reductase isolates belonged to three genera: Bacillus, Enterobacter and Raoultella. The bacteria symbionts aid in fixing nitrogen into ammonia which in turn is utilized to synthesize vitamins and amino acids for the host insect (Brune and Dietrich, 2015). The bacterial groups especially Proteobacteria and Firmicutes are reported to fix atmospheric nitrogen; and the genus Enterobacter contributed to

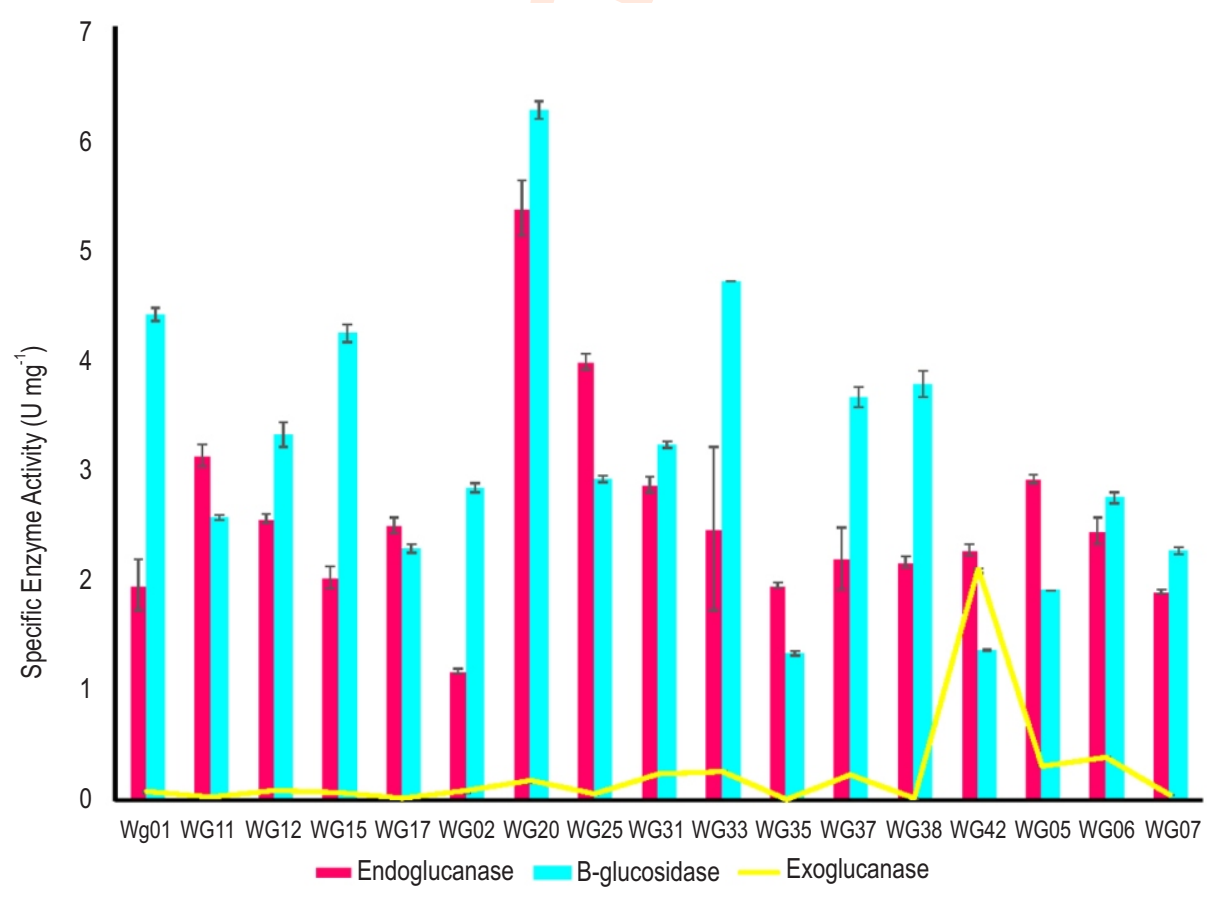

Fig. 1: Specific enzyme activity of gut bacterial isolates showing varying levels of endoglucanase, beta-glucosidase and exoglucanase activity. 


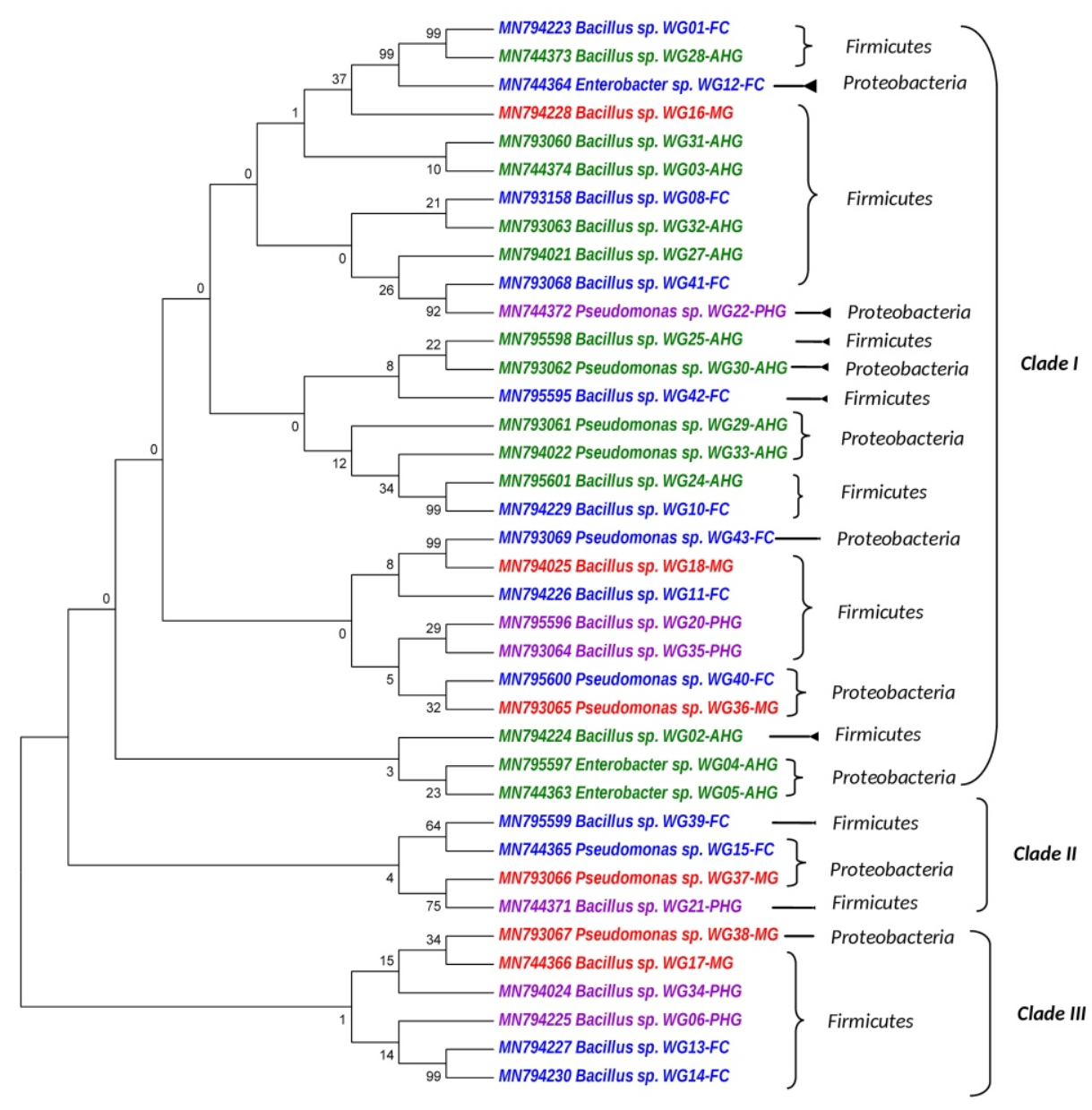

Fig. 2: Phylogenetic tree showing evolutionary relationships of gut bacteria isolated from A. dimidiata. Bacterial isolates highlighted with same color were identified from the same gut compartment.
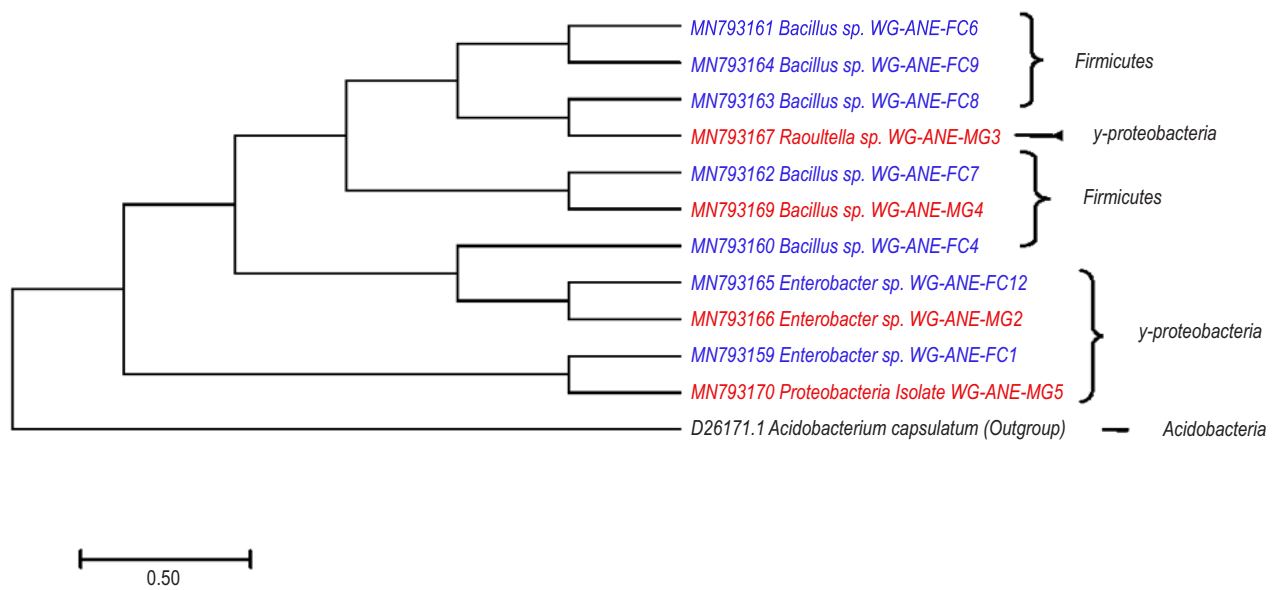

Fig. 3: Phylogenetic tree showing evolutionary relationships of anaerobic gut bacteria isolated from A. dimidiata. Bacterial isolates highlighted with same color were identified from the same gut compartment. 
host nutrition by fixing atmospheric nitrogen in wood boring beetles (Hernández-García et al., 2017). Zhang et al. (2018) indicated that the fermentation chamber is a typically anoxic environment containing obligate and facultative anaerobic bacteria believed to be critical in polysaccharide digestion, thus it is presumed that being an anaerobic environment, some of these anaerobic bacteria housed in the fermentation chamber may also be involved in ammonium oxidation (anammox).

Phylogenetic relationship analyses of culturable aerobic and facultative anaerobic gut bacteria $16 \mathrm{~S} r R N A$ gene sequences from $A$. dimidiata (Fig. 2, 3) showed that Firmicutes as the dominant phyla with Bacillus as the dominant genus with twentysix different species for aerobic bacteria isolates and six bacterial isolates for facultative anaerobic isolates. The proteobacteria formed the second dominant phyla comprising the genus Pseudomonas and Enterobacter with ten and four bacterial isolates for aerobic culturable gut bacteria whereas Raoutella, Enterobacter and a proteobacteria isolate WG-ANE-MG5 isolated from the midgut for anaerobic gut bacteria isolates. In addition to the two groups (Firmicutes and Proteobacteria) forming major clades, it is interesting to note that bacteria isolates, some even belonging to different genera, isolated from the same or adjacent gut compartments tended to cluster together suggesting a close relationship between these isolates compared to other isolates. However, the occurrence of Bacillus as the only dominant culturable gut bacteria in A. dimidiata suggests that this insect may have limited culturable gut bacterial diversity. This study provides information on important culturable gut bacteria of $A$. dimidiata that have cellulolytic, lipolytic and nitrate reductase activities which may be of significance in biotechnology and environmental remediation such as degradation of cellulosic substances from agricultural waste.

\section{Acknowledgments}

The authors gratefully acknowledge the help and support given by the ICAR-Indian Agricultural Research Institute, New Delhi and NAHEP-CAAST programme of Indian Council of Agricultural Research, New Delhi and Indian Council for Cultural Relations, Government of India for their support for this research programme. Special thanks should go to members of the Insect Molecular Genetics and Microbial Genetics laboratories of the Division of Entomology and Division of Microbiology, ICAR-IARI, for their assistance.

\section{References}

Akami, M., N.Y. Njintang, O.A. Gbaye, A.A. Andongma, M.A. Rashid, C.Y. Niu and E.N. Nukenine: Gut bacteria of the cowpea beetle mediate its resistance to dichlorvos and susceptibility to Lippia adoensis essential oil. Sci. Rep., 9, 6435 (2019).

Bhattacharyya, B., S. Bhagawati, H. Mishra, D. Gogoi, K. Pathak, S. Bhattacharjee and S. Borkotoki: Evaluation of some granular insecticides against white grub, Lepidiota mansueta B. in potato (Solanum tuberosum L.). J. Entomol. Zool. Stud., 5, 1441-1444 (2017).

Brune, A. and C. Dietrich: The gut microbiota of termites: digesting the diversity in the light of ecology and evolution. Ann. Rev. Microbiol., 69, 145-166 (2015).

Egert, M., B. Wagner, T. Lemke, A. Brune, and M.W. Friedrich: Microbial community structure in midgut and hindgut of the humus-feeding larva of Pachnoda ephippiata (Coleoptera: Scarabaeidae). Appl. Environ. Microbiol., 69, 6659-6668 (2003).

Feng, W., X.Q. Wang, W. Zhou, G.Y. Liu and Y.J. Wan: Isolation and characterization of lipase-producing bacteria in the intestine of the silkworm, Bombyx mori, reared on different forage. J. Insect Sci., 11,135 (2011).

Felsenstein, J.: Confidence limits on phylogenies: An approach using the bootstrap. Evolution, 39, 783-791 (1985).

Gupta, R., N. Gupta and P. Rathi: Bacterial lipases: An overview of production, purification and biochemical properties. Appl. Microbiol. Biotechnol., 64, 763-781 (2004).

Hall, T. A.: BioEdit: A user-friendly biological sequence alignment editor and analysis program for Windows 95/98/NT. In: Nucleic Acids Symposium Series. Information Retrieval Ltd., London, 41, 95-98 (1999).

Handique, G., A. Phukan, B. Bhattacharyya, A.A.L.H. Baruah, S.W. Rahman and R. Baruah: Characterization of cellulose degrading bacteria from the larval gut of the white grub beetle Lepidiota mansueta (Coleoptera: Scarabaeidae). Arch. Insect Biochem., 94, e21370 (2017).

Huang, S. and H. Zhang: The impact of environmental heterogeneity and life stage on the hindgut microbiota of Holotrichia parallela larvae (Coleoptera: Scarabaeidae). PLOS ONE, 8, e57169 (2013).

Huang, S.W., H.Y. Zhang, S. Marshall and T.A. Jackson: The scarab gut: A potential bioreactor for bio-fuel production. Insect Sci., 17, 175183 (2010).

Huang, S., P. Sheng and H. Zhang: Isolation and identification of cellulolytic bacteria from the gut of Holotrichia parallela larvae (Coleoptera: Scarabaeidae). Int. J. Mol. Sci., 13, 2563-2577 (2012).

Henrissat, B. and A. Bairoch: New families in the classification of glycosyl hydrolases based on amino acid sequence similarities. Biochem. J., 293, 781-788 (1993).

Hernández-García, J.A., C.I. Briones-Roblerol, F.N. Rivera-Orduña and G. Zúñiga: Revealing the gut bacteriome of Dendroctonus bark beetles (Curculionidae: Scolytinae): Diversity, core members and co-evolutionary patterns. Sci. Rep., 7, 13864 (2017).

Jackson, T.A. and M.G. Klein: Scarabs as pests: A continuing problem. Coleopterists Bulletin, 60, 102-119 (2006).

Jones, A.G., C.J. Mason, G.W. Felton and K. Hoover: Host plant and population source drive diversity of microbial gut communities in two polyphagous insects. Sci. Rep., 9, 2792 (2019).

Kothari, V.V., R.K. Kothari, C.R. Kothari, V.D. Bhatt, N.M. Nathani, P.G. Koringa, C.G. Joshi and B.R.M. Vyas: Genome sequence of salttolerant Bacillus safensis strain VK, isolated from saline desert area of Gujarat, India. Genome. Announc., 1, e00671-13 (2013).

Kumar, D, R. Parshad and V.K. Gupta: Application of a statistically enhanced, novel, organic solvent stable lipase from Bacillus safensis DVL-43. Int. J. Biol. Macromol., 66, 97-107 (2014).

Lemke, T., U. Stingl, M. Egert, M.W. Friedrich and A. Brune: Physicochemical conditions and microbial activities in the highly alkaline gut of the humus-feeding larva of Pachnoda ephippiata (Coleoptera: Scarabaeidae). Appl. Environ. Microbiol., 69, 66506658 (2003).

Lisdiyanti, P., E. Suyanto, N.F. Gusmawati and W. Rahayu: Isolation and characterization of cellulase produced by cellulolytic bacteria from peat soil of Ogan Komering llir, South Sumatera. Int. J. Environ. Bioen., 3, 145-153 (2012). 
Liu, R., W. Wang, X. Liu, Y. Lu, T. Xiang, W. Zhou and Y. Wan: Characterization of a lipase from the silkworm intestinal bacterium Bacillus pumilus with antiviral activity against Bombyx mori (Lepidoptera: Bombycidae) Nucleopolyhedrovirus in-vitro. J. Insect Sci., 18, 3 (2018).

Majeed, M.Z., E. Miambi, I. Barois, R. Randriamanantsoa, E. Blanchart and A. Brauman: Contribution of white grubs (Scarabaeidae: Coleoptera) to $\mathrm{N}_{2} \mathrm{O}$ emissions from tropical soils. Soil Biol. Biochem., 75, 37-44 (2014).

Mika, N., H. Zorn and M. Rühl: Insect-derived enzymes: A treasure for industrial biotechnology and food biotechnology. In: Yellow Biotechnology II. Springer, Berlin, Heidelberg, pp. 1-17 (2013).

Miller, G.L.: Use of dinitrosalicylic acid reagent for determination of reducing sugar. Anal. Chem., 31, 426-428 (1959).

Rajeshkumar, M.P., V.S. Mahendran and V. Balakrishnan: Isolation and identification of lipase producing organisms from diverse soil samples of Kolli hills. Int. J. Curr. Microbiol. Appl. Sci., 2, 205-210 (2013).

Santana, C., L. Barbosa, I. Júnior, T. Nascimento, C. Dornelas and L. Grillo: Lipase activity in the larval midgut of Rhynchophorus palmarum: Biochemical characterization and the effects of reducing agents. Insects, 8, 100 (2017).
Taggar, M.S.: Insect cellulolytic enzymes: Novel sources for degradation of lignocellulosic biomass. J. Appl. Nat. Sci., 7, 625-630 (2005).

Tamura, K., M. Nei and S. Kumar: Prospects for inferring very large phylogenies by using the neighbor-joining method. Proc. Natl. Acad. Sci. USA, 101, 11030-11035 (2004).

Theurkar, S.V., S.B. Patil, M.K. Ghadage, Y.B. Zaware and S.S. Madan: Distribution and abundance of white grubs (Coleoptera: Scarabaeidae) in Khed Taluka, part of Northern Western Ghats, MS, India. Int. Res. J. Biol. Sci., 1, 1-6 (2012).

Watanabe, H. and G. Tokuda: Cellulolytic systems in insects. Annu. Rev. Entomol., 55, 609-632 (2010).

Zhang, Z.Y., Y. Yuan, M.W. Ali, T. Peng, W. Peng, M.F. Raza, Y. Zhao and H. Zhang: Cultivable anaerobic and aerobic bacterial communities in the fermentation chambers of Holotrichia parallela (Coleoptera: Scarabaeidae) larvae. PloS ONE, 13, e0190663 (2018).

Zhang, H. and T.A. Jackson: Autochthonous bacterial flora indicated by PCR-DGGE of $16 S$ rRNAgene fragments from the alimentary tract of Costelytra zealandica (Coleoptera: Scarabaeidae). J. Appl. Microbiol., 5, 1277-1285(2008).

Zibaee, A., M. Fazeli-Dinan and C. License: Purification and characterization of a digestive lipase in Naranga aenescens Moore (Lepidoptera: Noctuidae). SOAJ., 1, 38-54 (2012). 